\title{
Nitrogen budget in intensive cultures of Litopenaeus vannamei in mesocosms, with zero water exchange and artificial substrates
}

Balance de nitrógeno en cultivos intensivos de Litopenaeus vannamei en mesocosmos, sin recambios de agua y con sustratos artificiales

\author{
Juan M. Audelo-Naranjoํㅜ Luis R. Martínez-Córdova² ${ }^{2}$ and Domenico Voltolina ${ }^{3}$ \\ ${ }^{1}$ Universidad Autónoma de Sinaloa, Facultad de Ciencias del Mar, Paseo Claussen s/n, Col. Los Pinos, P.O. Box 610, Mazatlán, \\ Sinaloa, México \\ ${ }^{2}$ Universidad de Sonora, Departamento de Investigaciones Científicas y Tecnológicas, Rosales y Blvd. Luis Encinas s/n, P.O. Box \\ 1819, Hermosillo, Sonora, México \\ ${ }^{3}$ Centro de Investigaciones Biológicas del Noroeste, Laboratorio UAS-CIBNOR, P.O. Box 1132, Mazatlán, Sinaloa, México. \\ voltolin04@cibnor.mx
}

\begin{abstract}
After 29 days without water exchanges, $55 \%$ of the total nitrogen (N) inputs were retained as shrimp biomass in $1 \mathrm{~m}^{3}$ cultures of juvenile Litopenaeus vannamei with artificial substrates (Aquamats ${ }^{\circledR}$ ), in comparison to 37.2 to $44.8 \%$ without Aquamats. The $N$ discharged with the effluent was $1.8-2.3 \%$ of the inputs, and the sediments contained $35.9-37.3 \%$ of the $\mathrm{N}$ inputs without Aquamats and 14.7 to $13.6 \%$ with Aquamats. In these, close to $16 \%$ of the $\mathrm{N}$ inputs were in the periphyton, indicating that additional substrates are an attractive alternative for nutrient recycling in shrimp farms operating as closed systems.
\end{abstract}

Key words: Aquamats ${ }^{\circledR}$, periphyton, nitrogen recycling

\section{INTRODUCTION}

The general scientific consensus is that nitrogen enrichment is a threat to the ecological balance of coastal and other aquatic ecosystems (Nixon 1995, Howarth et al. 2000). For this reason, the control of the nitrogen content of human wastewaters should be an essential part of the policies aiming to reduce coastal eutrophication (Howarth \& Marino 2006).

Aquaculture may be an important source of nitrogen disposed to receiving water bodies because, on average, less than $30 \%$ of the nitrogen supplied to fish and shrimp ponds as food or fertilizer is recovered as biomass of the target species. Most of the remainder enters the water as ammonia through excretion or ammonification of the organic $\mathrm{N}$ present in uneaten food and faeces (Funge-Smith \& Briggs 1998, Jackson et al. 2003).

This is ultimately lost to the system as dissolved or particulate $\mathrm{N}$, either in the pond sediments (Avnimelech \& Ritvo 2003), or through the water discharged daily to maintain water quality, thus becoming a significant source of eutrophication in coastal areas (Lorenzen 1999, TeichertCoddington et al. 2000, Burford et al. 2002).
There are several wastewater treatment systems used in aquaculture that remove nitrogen and organic wastes and thus reduce their impact on the environment. However, there is an attractive alternative which exploits the activity of the microbiota present in the culture system, and consists in promoting the formation and growth of microbial flocs in the water column, or of mixed microalgae-bacteria mats (periphyton) on submerged substrates (Avnimelech 2009).

Both are appropriate solutions for problems of water quality, because bacteria and microalgae have a positive effect on water quality since the dissolved and particulate nitrogen species are incorporated into algal and microbial biomass. Both have the added advantage that this biomass increases the availability of natural food for the cultured organisms, and therefore they may improve the economic performance of the culture system (Azim et al. 2003, Crab et al. 2007).

In this study, we evaluated the efficiency of artificial submerged substrates as nitrogen recyclers, determining the nitrogen budget in mesocosms used as experimental shrimp culture systems, maintained during one month with zero water exchanges and with two initial stocking densities. 


\section{Material And Methods}

The experiment was run on the grounds of a commercial semi-intensive shrimp farm located close to the Urías estuary (Mazatlán, Sinaloa, NW Mexico), which is the source of seawater for the daily water exchanges of the shrimp farm.

One week before the experiment, $10 \mathrm{~cm}$-deep layers of the natural sediment of the same shrimp pond from which we obtained the experimental organisms were added to 12 circular $1.1 \mathrm{~m}^{3}$ tanks (bottom area: $1.1 \mathrm{~m}^{2}$, wall surface: $3.7 \mathrm{~m}^{2}$ ). Tanks were filled with $1 \mathrm{~m}^{3}$ of $300-\mu \mathrm{m}$ filtered estuary water.

One day before stocking, $7.1 \mathrm{~m}^{2}$ (both sides) of artificial substrates (Aquamats, Meridian Applied Technology Systems, Calverton, Maryland, USA), which had been left in an operating shrimp pond during 24 days to allow formation of the biofilm, were placed vertically into six tanks forming a circular inner wall at a distance of about $10 \mathrm{~cm}$ from the tank walls. This addition increased by $150 \%$ the surface available as substrate to the shrimps stocked in these tanks. The remaining six tanks served as controls.

The following day, Litopenaeus vannamei juveniles with a mean wet weight of $2.7 \pm 0.2 \mathrm{~g}$ were stocked in triplicate tanks with or without submerged substrates, with initial stocking biomass of 545 and $727 \mathrm{~g} \mathrm{~m}^{-2}$, respectively (calculated densities of close to 200 and 270 organisms $\left.\mathrm{m}^{-3}\right)$.

The treatment assigned to each mesocosm was determined at random, using a $2 \times 2 \times 3$ completely randomized block experimental design (presence or absence of additional substrate with two initial stocking densities, in triplicate for each treatment).

The experiment lasted for $29 \mathrm{~d}$, from May $26^{\text {th }}$ until June 23 ${ }^{\text {rd }}$, 2009. Food (Camaronina 35\%, Agribrands Purina Mexico, Cuautitlán, Mexico State, Mexico) was supplied twice daily (08:00 and 18:00 h) in feeding trays, and the daily ration was adjusted according to its consumption (Clifford 1997); mild aeration was provided with one airstone to avoid thermal stratification, and there were no daily water exchanges. However, estuary water was added once weekly to replace the volume lost to evaporation (mean weekly loss: $5 \%$ of the water volume).

Temperature and oxygen concentration were measured twice daily (8:00 and 18:00) using an YSI 57 oxygen meter (YSI Incorporated, Yellow Springs, OH, USA). Salinity and $\mathrm{pH}$ were measured at 12:00 with an Atago S/Mill-E refractometer (Atago Co. Ltd., Tokio, Japan) and a HI
98150 Hanna portable pH meter (HANNA Instruments, Woonsocket, RI, USA), respectively. The mean values between treatments were compared with two-way blockANOVA tests, with significant level of 0.05 .

The concentrations of the dissolved nitrogen species were determined in triplicate $250 \mathrm{ml}$ samples of the water used to fill the tanks, and of that used weekly to restore the water level. The samples were filtered through Whatman GF-C filters, and the concentrations of dissolved $\mathrm{N}-\mathrm{NO}_{3}{ }_{3}^{-} \mathrm{N}_{-} \mathrm{NO}_{2}^{-}, \mathrm{N}_{-} \mathrm{NH}_{4}{ }^{+}$and dissolved organic $\mathrm{N}$ were determined as in Strickland \& Parsons (1972).

The organic nitrogen content of the particles retained on the filters was determined as described by Holm-Hansen (1968). The initial and final organic nitrogen content of the sediment and of the accompanying meiofauna (determined in triplicate samples at the time of addition to the mesocosms, and of composite samples of the sediment, obtained at the end of the experiment from the center and sides of each tank), of shrimp biomass and of the periphyton present on the artificial substrates (obtained scraping with a scalpel a known area of the substrate: Burford et al. 2004) were determined with the Kjeldahl method (AOAC 2005). This method was also used to determine the organic $\mathrm{N}$ of weekly samples of shrimp feed.

The mean concentrations of the dissolved and particulate nitrogen species determined in triplicate samples of the water discharged at the end of the experiment were compared with two-way ANOVA tests, after natural log transformation when the data were not normal or homoscedastic. The different means were separated with Holm-Sidak tests and in all cases the critical probability level was $\alpha=0.05$.

The nitrogen budget was calculated considering that, with the exception of some shrimps escaped from the tanks, which were collected, analyzed, and added to the final outputs, there were no nitrogen losses from the beginning to the end of the experiment, in view that the systems were maintained without water exchanges.

Therefore the budget was calculated as:

$\Sigma \mathrm{N}$ of the inputs $=\Sigma \mathrm{N}$ of the outputs + losses not considered

$\Sigma$ inputs: (initial $\mathrm{N}$ content of sediment and periphyton $+\mathrm{N}$ content of the total shrimp feed supplied to each tank $+\mathrm{N}$ content (sum of dissolved and particulate species) of the water used for tank filling plus weekly additions $+\mathrm{N}$ content of juveniles stocked); $\Sigma$ outputs ( $\mathrm{N}$ content of the shrimp biomass harvested + final $\mathrm{N}$ content of the sediment and periphyton + sum of the dissolved and particulate $\mathrm{N}$ 
determined in the water discharged at the end of the experiment).

\section{Results AND Discussion}

Throughout the experiment, the mean temperature and oxygen concentrations of each mesocosm ranged between $28.6 \pm 1.1$ and $28.9 \pm 1.1^{\circ} \mathrm{C}$ and from $4.0 \pm 0.6$ to $4.3 \pm 0.6$ $\mathrm{mg} \mathrm{l}^{-1}$ for the morning readings. The respective evening values were $31.6 \pm 1.4$ to $31.9 \pm 1.0^{\circ} \mathrm{C}$, and $4.4 \pm 0.6$ to 4.6 $\pm 0.5 \mathrm{mg} \mathrm{l}^{-1}$. The mean salinity and $\mathrm{pH}$ values varied from $42.7 \pm 2.3$ to $42.9 \pm 2.1 \%$ and between $7.5 \pm 0.1$ and $7.6 \pm$ 0.2 . In all cases, there were no differences between replicates and treatments.

The total $\mathrm{N}$ concentration of the water used to fill the tanks was $2.42 \mathrm{mg} \mathrm{l}^{-1}$, of which $1.61 \mathrm{mg}$ (66.5\%) was present as dissolved organic $\mathrm{N}$, and 0.38 and $0.42 \mathrm{mg}$ (15.7 and $17.4 \%$ ) were total ammonia and particulate organic $\mathrm{N}$.

With one exception $\left(\mathrm{NH}_{4}^{+}\right.$in the $800 \mathrm{~g}$ treatment with added substrate) the final concentrations of the dissolved inorganic species were higher than the initial values and, possibly as a result of a more active nitrification by the microbiota present on the additional substrates (Bratvold \& Browdy 2001, Erler et al. 2004), the final ammonia levels were significantly lower, and conversely those of nitrites were higher, in the mesocosms with Aquamats than in those without Aquamats (Table 1).

The initial concentration of dissolved organic $\mathrm{N}$ was higher than the final values, indicating an effective recycling in these closed systems. This was particularly evident in the mesocosms with Aquamats and high stocking density, which had the lowest concentration of dissolved organic $\mathrm{N}$ although they had the highest value of particulate $\mathrm{N}$ (Table 1).

The major $\mathrm{N}$ input to the experimental systems was the formulated shrimp feed (mean $\mathrm{N}$ content 5.6\%, DW), ranging from 95.4 to $117.3 \mathrm{~g} \mathrm{~m}^{-3}$ (75.9 to $78.8 \%$ ). These percentages are lower than the input calculated by Jackson et al. (2003) for an intensive shrimp farm with high water exchanges, which was close to $90 \%$, and lie at the low end of the $76-92 \%$ range observed by Thakur \& Lin (2003) in a zero water exchange intensive system.

In comparison to other experimental systems, this difference is explained by the fact that the initial stocking was with $2.7 \mathrm{~g}$ juvenile shrimp, rather than with 0.01-0.02 g postlarvae used for stocking commercial farms. Therefore, the biomass stocked was the second highest $\mathrm{N}$ input (21.5 and $28.7 \mathrm{~g} ; 16.7$ to $19.3 \%$ ).

The water used for daily exchanges may be a significant $\mathrm{N}$ input in semi-intensive open systems (TeichertCoddington et al. 2000, Miranda-Baeza et al. 2007), but its importance is far lower in intensive farms (Briggs \& Funge-Smith 1994, Funge-Smith \& Briggs 1998, Jackson et al. 2003). In this case, the mesocosms were handled as closed systems and the contribution of the $\mathrm{N}$ content of seawater was between 1.9 and $2.3 \%$. The $\mathrm{N}$ added to each mesocosm with the sediment and with the biofilm on the artificial substrates were 0.9 to $1.1 \%$, and 1.9 to $2.2 \%$ of the total inputs (Table 2).

Table 1. Mean final concentrations $\left(\mathrm{mg} \mathrm{l}^{-1}\right) \pm$ standard deviations of the nitrogen species in $1 \mathrm{~m}^{3}$ mesocosms, with initial stocking densities of 600 and $800 \mathrm{~g} \mathrm{~m}^{-3}$ of Litopenaeus vannamei, with (AM) or without Aquamats (NS) / Concentraciones medias finales $\left(\mathrm{mg} \mathrm{l}^{-1}\right) \pm$ desviaciones estándar de las especies de nitrógeno en mesocosmos de $1 \mathrm{~m}^{3}$, con biomasa inicial de 600 y $800 \mathrm{~g} \mathrm{~m}^{-3}$ de Litopenaeus vannamei, con (AM) o sin Aquamats (NS)

\begin{tabular}{|c|c|c|c|c|c|}
\hline $\mathrm{N}$ species & Initial & $\mathrm{AM}_{600}$ & $\mathrm{NS}_{600}$ & $\mathrm{AM}_{800}$ & $\mathrm{NS}_{800}$ \\
\hline$* \mathrm{~N}-\mathrm{NH}_{4}{ }^{+}$ & $0.38 \pm 0.02$ & $0.51 \pm 0.03 b$ & $0.80 \pm 0.01 \mathrm{c}$ & $0.05 \pm 0.01 \mathrm{a}$ & $1.28 \pm 0.01 \mathrm{~d}$ \\
\hline $\mathrm{N}-\mathrm{NO}_{2}^{-}$ & $0.03 \pm 0.01$ & $0.29 \pm 0.04 \mathrm{ab}$ & $0.09 \pm 0.01 \mathrm{a}$ & $0.52 \pm 0.21 \mathrm{c}$ & $0.13 \pm 0.08 \mathrm{a}$ \\
\hline${ }^{*} \mathrm{~N}-\mathrm{NO}_{3}{ }^{-}$ & $0.01 \pm 0.01$ & $0.74 \pm 0.02 b$ & $0.71 \pm 0.01 b$ & $0.77 \pm 0.01 \mathrm{~b}$ & $0.62 \pm 0.07 \mathrm{a}$ \\
\hline *Dissolved organic $\mathrm{N}$ & $1.61 \pm 0.02$ & $0.96 \pm 0.04 b$ & $1.05 \pm 0.02 b$ & $1.19 \pm 0.44 \mathrm{~b}$ & $0.51 \pm 0.05 \mathrm{a}$ \\
\hline Total dissolved $\mathrm{N}$ & $2.00 \pm 0.03$ & $2.49 \pm 0.11 \mathrm{a}$ & $2.65 \pm 0.03 \mathrm{a}$ & $2.52 \pm 0.24 \mathrm{a}$ & $2.54 \pm 0.20 \mathrm{a}$ \\
\hline *Particulate organic $\mathrm{N}$ & $0.42 \pm 0.02$ & $0.09 \pm 0.01 \mathrm{a}$ & $0.15 \pm 0.01 \mathrm{a}$ & $0.31 \pm 0.35 \mathrm{a}$ & $0.64 \pm 0.04 \mathrm{~b}$ \\
\hline Total N & $2.42 \pm 0.05$ & $2.58 \pm 0.11 \mathrm{a}$ & $2.79 \pm 0.02 \mathrm{ab}$ & $2.83 \pm 0.16 \mathrm{~b}$ & $3.18 \pm 0.17 \mathrm{c}$ \\
\hline
\end{tabular}

Different letters indicate significant differences between values in the same row (two-way ANOVAs, $\alpha=0.05, a \leq a b \leq b$ and $a<b<c<d$ ). $(*=\ln$ transformation) 
In all cases, most of the $\mathrm{N}$ was retained within the mesocosms, since the water discharged contained only between 1.8 and $2.3 \%$ of the total nitrogen inputs. However, close to $55 \%$ of the $\mathrm{N}$ added was recovered as shrimp biomass in the mesocosms with artificial substrates, with which the respective mean biomass harvested (wet weight, with a mean $\mathrm{N}$ content of $3.58 \pm 0.13 \%$ ) for the 600 and 800 g treatments were $1969.6 \pm 75.9$ and 2221.6 $\pm 44.5 \mathrm{~g}$. The respective individual wet weights were 8.9 \pm 1.6 and $8.5 \pm 1.3 \mathrm{~g}$, with percentages of survival of 96.7 \pm 2.3 and $90.9 \pm 2.8 \%$ ).

In comparison, the mean values of biomass harvested in the control mesocosms were $1516.0 \pm 101.9$ and 1560.8 $\pm 76.3 \mathrm{~g}$, the individual wet weights were $8.5 \pm 1.3$ and 7.1 $\pm 1.6 \mathrm{~g}$ and the percentages of survival were $84.0 \pm 7.5$ and $74.5 \pm 9.5 \%$. The respective percentages of $\mathrm{N}$ recovered as shrimp biomass were $44.8 \%$ (low stocking) and $37.2 \%$ (high stocking) (Table 2).
By the end of the experiment, the organic $\mathrm{N}$ contents of the artificial substrates represented $16 \%$ of the total $\mathrm{N}$ inputs, which were not considered losses since they were still available for shrimp feeding, and their positive effect was made evident by the low $\mathrm{N}$ content of the sediments. These contained only between 14 and $13.6 \%$ of the total $\mathrm{N}$ inputs, which are less than $50 \%$ of the percentages determined in the control treatments (37.3 and 35.9\% for the mesocosms started with 600 and $800 \mathrm{~g}$ ).

In traditional cultures, the organic wastes generated by the feeding process accumulate in the pond bottom. This leads to the development of microaerobic or anaerobic conditions, slow nitrification and slow rate of organic matter recycling within the natural food web of the pond. As a consequence, toxic metabolites increase and must be removed with daily water exchanges of the pond water, resulting in a net nitrogen loss (Piedrahita 2003).

Table 2. Nitrogen budget after 29 days of culture of Litopenaeus vannamei in $1 \mathrm{~m}^{3}$ mesocosms with Aquamats (AM) and with no added substrate (NS), with initial stocking densities of 600 and $800 \mathrm{~g} \mathrm{~m}^{-3}$. Mean values and standard deviations of the amounts $\left(\mathrm{g} \mathrm{m}^{-3}\right)$ added to the mesocosms (input), and of the amounts determined in the different compartments at the end of the experiment (output). Relative contributions to the budget (\%) in parenthesis / Balance de nitrógeno después de 29 días de cultivo de Litopenaeus vannamei en mesocosmos de $1 \mathrm{~m}^{3}$ con Aquamats (AM) y sin sustrato adicional (NS), con densidades iniciales de siembra de 600 y $800 \mathrm{~g} \mathrm{~m}^{-3}$. Valores medios y desviaciones estándar de las cantidades $\left(\mathrm{g} \mathrm{m}^{-3}\right)$ agregadas a los mesocosmos (ingresos) y de las determinadas en diferentes componentes del sistema al final del experimento (egresos). En paréntesis se dan las contribuciones relativas (en \%) al balance total

\begin{tabular}{lcccc}
\hline & $\mathrm{AM}_{600}$ & $\mathrm{NS}_{600}$ & $\mathrm{AM}_{800}$ & $\mathrm{NS}_{800}$ \\
\hline Inputs & & & & \\
$\quad$ Feed & $100.0 \pm 3.0(77.4)$ & $95.4 \pm 1.1(78.8)$ & $112.8 \pm 3.1(75.9)$ & $117.3 \pm 2.4(78.2)$ \\
Biomass stocked & $21.5 \pm 0.1(16.7)$ & $21.5 \pm 0.1(17.9)$ & $28.7 \pm 0.1(19.3)$ & $28.7 \pm 0.1(19.1)$ \\
Water & $2.8 \pm 0.1(2.2)$ & $2.8 \pm 0.1(2.3)$ & $2.8 \pm 0.1(1.9)$ & $2.8 \pm 0.1(1.9)$ \\
Biofilm & $3.5 \pm 0.4(2.7)$ & -- & $2.9 \pm 0.9(2.0)$ & -- \\
Sediment & $1.4 \pm 0.1(1.1)$ & $1.4 \pm 0.1(1.1)$ & $1.4 \pm 0.1(0.9)$ & $1.4 \pm 0.1(0.9)$ \\
TOTAL & $129.1(100.0)$ & $121.0(100.0)$ & $148.5(100.0)$ & $150.4(100.0)$ \\
Outputs & & & & $52.0 \pm 1.6(55.2)$ \\
Biomass harvested & $70.5 \pm 2.7(54.6)$ & $54.3 \pm 3.6(44.8)$ & $55.9 \pm 2.7(37.2)$ \\
Sediment & $19.0 \pm 0.7(14.7)$ & $45.1 \pm 0.6(37.3)$ & $20.3 \pm 0.6(13.6)$ & $53.9 \pm 0.1(35.9)$ \\
Biofilm & $20.5 \pm 0.5(15.9)$ & -- & $23.8 \pm 0.1(16.0)$ & -- \\
Water & $2.6 \pm 0.1(2.0)$ & $2.8 \pm 0.2(2.3)$ & $2.8 \pm 0.2(1.8)$ & $3.2 \pm 0.2(2.3)$ \\
Escapes & $9.0(7.0)$ & $7.7(6.4)$ & $6.0(4.0)$ & $17.2(11.4)$ \\
TOTAL & $121.6(94.1)$ & $109.8(90.7)$ & $134.9(90.8)$ & $130.2(86.6)$ \\
Difference & $7.6(5.9)$ & $11.2(9.3)$ & $13.0(9.2)$ & $19.8(13.4)$ \\
\hline
\end{tabular}


This loss and the accumulation of organic wastes in the pond bottom may be avoided by additional substrates, especially those designed to adsorb particles with high efficiency such as Aquamats, since these particles are adsorbed on the vertical substrates which are suspended in the water column. In our experiment, the aeration provided to all treatments enhanced aerobic processes, especially nitrification (that is poor or absent in microaerobic or anaerobic sediments), and the lower ammonium and higher nitrite levels found in the mesocosms with added substrate, indicate that nitrification was more efficient in these treatments.

Thus, degradation of organic matter was faster in the tanks with Aquamats than in the controls, and additionally the shrimp could feed on the biofilm and organic detritus present on the substrates, allowing an effective recycling of the unused $\mathrm{N}$ of the shrimp feed, which accumulated in the sediments of the control treatments.

The losses of $\mathrm{N}$ caused by shrimp escape ranged from 4.0 to $11.4 \%$, leaving unexplained between 5.9 and $13.4 \%$ of the inputs. Considering the $\mathrm{NH}_{3}-\mathrm{NH}_{4}{ }^{+}$equilibrium at the mean $\mathrm{pH}$, temperature and salinity values determined in this experiment, between 1.7 and $2.5 \%$ of the dissolved ammonia was present in the molecular species (Khoo et al. 1977). This might account for a part of the missing fraction, although a more important percentage was probably present as additional biofilm on the tank walls which, in closed shrimp monoculture systems, may account from $3.7 \%$ to $13.3 \%$ of the total N inputs (Qi et al. 2001).

The shrimp farming industry is facing several major challenges, in part related to the perceived threat to the environment represented by the quality of its effluents, and also because of the need to increase the economic performance of shrimp farms in view of the increasingly higher costs of production. One important common source of these challenges is the high protein content of the feed used in shrimp farming, which is directly related to the cost of shrimp feed, and their inefficient conversion into shrimp biomass, which affects the production costs and the quality of the effluents.

In open culture systems, close or more than $70 \%$ of the total $\mathrm{N}$ inputs is discharged with the effluent water or remains in the sediment, and the amount recovered as shrimp biomass may be as low as 11 to $25 \%$ (Briggs \& Funge-Smith 1994, Teichert-Coddington et al. 2000, Jackson et al. 2003, Miranda-Baeza et al. 2009). This is less than $50 \%$ of the $\mathrm{N}$ recovered in the harvests of our closed systems, especially in the treatments with additional substrates, in which the long residence time allowed the utilization of nitrogenous wastes by the natural biota. These served as additional food and allowed to recycle food wastes into valuable shrimp biomass.

\section{Acknowledgments}

In partial fulfillment for a Ph. D. degree at Centro de Investigaciones Biológicas del Noroeste of the first author, who acknowledges the support of CONACYT and PROMEP scholarships. V. Núñez-Martínez, O. ZamudioArmenta, José Madero-Pérez of the Academic Group 'Shrimp and Fish culture', and E. Romero-Beltrán (CRIP Mazatlán) helped with field and analytical work.

\section{LITERATURE CITED}

AOAC. 2005. Standard methods for the examination of water and wastewater, 1368 pp. American Public Health Association (APHA), American Water Works Association (AWWA), Water Environment Federation (WEF), Washington.

Avnimelech Y. 2009. Biofloc technology - a practical guide book, 182 pp .The World Aquaculture Society, Baton Rouge.

Avnimelech Y \& G Ritvo. 2003. Shrimp and fish pond soils: processes and management. Aquaculture 220: 549-567.

Azim ME, MCJ Verdegem, M Singh, AA van Dam \& MCM Beveridge. 2003. The effects of periphyton substrate and fish stocking density on water quality, phytoplankton, periphyton and fish growth. Aquaculture Research 34: 685695.

Bratvold D \& CL Browdy. 2001. Effects of sand sediment and vertical surfaces (AquaMats ${ }^{\mathrm{TM}}$ ) on production, water quality, and microbial ecology in an intensive Litopenaeus vannamei culture system. Aquaculture 195: 81-94.

Briggs MR \& SJ Funge-Smith. 1994. A nutrient budget of some intensive marine shrimp ponds in Thailand. Aquaculture Research 25: 789-811.

Burford MA, NP Preston, PM Glibert \& C Dennison. 2002. Tracing the fate of ${ }^{15} \mathrm{~N}$-enriched feed in an intensive shrimp system. Aquaculture 206: 199-216.

Burford MA, MJ Sellars, SJ Arnold, PJ Crocos \& NP Preston. 2004. Contribution of natural biota associated with substrates to the nutritional requirements of the post-larval shrimp, P. esculentus (Haswell) in high-density rearing systems. Aquaculture Research 35: 508-515.

Clifford HC. 1997. Manual de operación para el manejo de Super Shrimp en estanques, 105 pp. División de Servicios Técnicos, Super Shrimp, Mazatlán.

Crab R, Y Avnimelech, T Defoirdt, P Bossier \& W Verstraete. 2007. Nitrogen removal techniques in aquaculture for a sustainable production. Aquaculture 270: 1-14. 
Erler D, P Pollard, P Duncan \& W Knibb. 2004. Treatment of shrimp farm effluent with omnivorous finfish and artificial substrates. Aquaculture Research 35: 816-827.

Funge-Smith SJ \& MR Briggs. 1998. Nutrient budgets in intensive shrimp ponds: implications for sustainability. Aquaculture 164: 117-134.

Holm-Hansen O. 1968. Determination of particulate organic nitrogen. Limnology and Oceanography 13: 175-178.

Howarth RW \& R Marino. 2006. Nitrogen as the limiting nutrient for eutrophication in coastal marine ecosystems: evolving views over three decades. Limnology and Oceanography 51: 364-376.

Howarth RW, D Anderson, J Cloern, C Elfring, C Hopkinson, B Lapointe, T Malone, $\mathbf{N}$ Marcus, K McGlathery, A Sharpley \& D Walker. 2000. Nutrient pollution of coastal rivers, bays, and seas. Issues in Ecology 7: 1-15.

Jackson C, N Preston, PJ Thompson \& M Burford. 2003. Nitrogen budget and effluent nitrogen components at an intensive shrimp farm. Aquaculture 218: 397-411.

Khoo KH, CH Culberson \& RG Bates. 1977. Thermodynamics of the dissociation of ammonia ion in seawater from 5 to $40^{\circ} \mathrm{C}$. Journal of Solution Chemistry 6: 281-290.

Lorenzen K. 1999. Nitrogen recovery from shrimp pond effluent: dissolved $\mathrm{N}$ removal has greater overall recovery potential than particulate $\mathrm{N}$ removal, but requires higher rates of water exchange than presently used. Aquaculture Research 30: 923-928.
Miranda-Baeza A, D Voltolina, MA Brambilla-Gámez, MG Frías-Espericueta \& J Simental. 2007. Effluent characteristics and nutrient loading of a semi-intensive shrimp farm in NW Mexico. Vie et Milieu 57: 21-27.

Miranda A, D Voltolina, MG Frías-Espericueta, G IzaguirreFierro \& ME Rivas-Vega. 2009. Nutrient budget and nutrient discharges to the Gulf of California of a semiintensive shrimp farm (NW Mexico). Hidrobiológica 19: 43-48.

Nixon SW. 1995. Coastal marine eutrophication: a definition, social causes, and future concerns. Ophelia 41: 199-219.

Piedrahita RH. 2003. Reducing the potential environmental impact of tank aquaculture effluents through intensification and recirculation. Aquaculture 226(1-4): 35-44.

Qi Z-X, D-S Li, MP Zhang \& S-L Dhong. 2001. Comparative studies on nitrogen budgets of closed shrimp polyculture systems. Chinese Journal of Oceanology and Limnology 19: 233-242.

Strickland J \& JR Parsons. 1972. A practical handbook of seawater analysis. Fisheries Research Board of Canada Bulletin 169: 1-310.

Teichert-Coddington D, D Martínez \& E Ramírez. 2000. Partial nutrient budgets for semi-intensive shrimp farms in Honduras. Aquaculture 190: 139-154.

Thakur DP \& CK Lin. 2003. Water quality and nutrient budget in closed shrimp (Penaeus monodon) culture systems. Aquacultural Engineering 27: 159-176.

Recibido el 24 de mayo de 2010 y aceptado el 29 de junio de 2010 